\title{
MOTIVATION IN THE EDUCATIONAL PROCESS
}

\section{[MOTIVACIA V EDUKACNOM PROCESE]}

\author{
Erich Petlak
}

doi: 10.18355/PG.2020.9.2.2

\begin{abstract}
Motivation as a basic attribute of education is analyzed in the presented paper. The article does not describe all the theoretical aspects of motivation. The main presented idea is motivation and discusses about selected motvational theories that are not appreciated in the practice of education. The paper mainly analyzes theories: about justice, about the hierarchy of needs, the theory of expectations, goal setting, the theory of strengthening and three categories of needs. The research, which was attended by 168 teachers, showed that teachers pay attention to students' motivation, but still remain, respectively. they prefer the classic motivation. It means input and continuous motivational methods, evaluation of students, control as motivation, etc. Current approaches such as motivation through newer educational strategies are only gradually getting into education. In connection with motivation, we most often focus on the course of the teaching process and the teacher's activities. But it is less analyzed how are teachers motivated into their educational activities. In this context, the article presents what motivates or demotivates teachers in their pedagogical-didactic work.
\end{abstract}

\section{Key words}

Motivation, the theories of motivation, classical approaches of motivation, new educational strategies and motivation, teacher motivation

\begin{abstract}
Abstrakt
Autor sa v príspevku zaoberá motiváciou ako základným atribútom edukácie. V príspevku neopisuje všetky teoretické aspekty motivácie. Zameriava sa predovšetkým na podstatu motivácie a pripomína najmä vybrané motivačné teórie, ktoré nie sú v praxi edukácie doceňované. Pripomína teórie: spravodlivosti, hierarchie potrieb, očakávania, stanovenia ciel'ov, posilnenia a troch kategórií potrieb. Z prieskumu, ktorého sa zúčastnilo 168 učitel'ov vyplynulo, že učitelia motivácii žiakov pozornost' venujú, ale stále ostávajú, resp. uprednostňujú tzv, klasickú motiváciu, napr. vstupné a priebežné motivačné metódy, hodnotenie žiakov, kontrola ako motivácia a pod. Len postupne začínajú doceňovat' aj novšie prístupy, napr. motivácia prostredníctvom novších edukačných stratégií. V súvislosti s motiváciou sa najčastejšie sústred'ujeme na priebeh vyučovacieho procesu a činnosti učitel'a. Menej si všímame ako a čím sú motivovaní do svojej edukačnej činnosti učitelia. V tejto súvislosti autor uvádza čo učitel'ov motivuje alebo demotivuje do ich pedagogicko-didaktickej práce.
\end{abstract}




\section{Kl'účové slová}

motivácia, teórie motivácie, klasické motivačné prístupy, novšie edukačné stratégie a motivácia, motivácia učitel'a

\section{Úvod}

V súvislosti so snahami o zvyšovanie úrovne a výsledkov edukačného procesu sú v ostatných rokoch opisované a analyzované viaceré oblasti, ktoré pôsobia na výsledné efekty edukácie. Sme svedkami priam masívneho sústredenia pozornosti, napr. na psychodidaktické aspekty edukácie, na neurodidaktické pohl'ady, na inovačné stratégie edukácie, čoraz viac sa zdôrazňuje význam emocionality edukácie, v neposlednom rade sa pozornost' obracia aj na motivačné aspekty edukácie. Ani jedna z uvedených a mnohých d'alších oblastí nepatrí k niečomu čo by sme mohli označit' ako úplne nové. Ak sa zahĺbime do štúdia histórie didaktiky alebo aj pedagogickej psychológie, pripustíme konštatovanie, že nejde o celkom nové myšlienky alebo pohl'ady. Príkladom uvedeného môže byt', napr. neuropedagogika a neurodidaktika, o ktorých niektorí pedagógovia a psychológovia hovoria ako o „novom víne v starej fl'aši“. Samozrejme, týmto nijako nezaznávame a nepodceňujeme úsilie a snahy pedagógov a psychológov, ktorí sa uvedeným oblastiam venujú, rozpracúvajú ich, a čo je podstatné, aplikujú ich na nové zmenené podmienky edukácie, na ktorú kladie spoločnost' čoraz väčšie nároky. Zastávame stanovisko, že k takýmto oblastiam patrí aj motivácia žiakov do učebnej činnosti. Akiste všetci sa zhodneme na tom, že motiváciu môžeme označit' ako klasickú požiadavku oddávna spájanú s edukáciou. Určite sa však zhodneme aj na tom, že jej význam v ostatných desat'ročiach významne vzrástol - náročnejší obsah vzdelania a z neho vyplývajúce náročnejšie požiadavky na žiakov, významné zmeny v živote spoločnosti, ktorá ponúka rôzne možnosti využívania času, čo spôsobuje, že čast' mladých l'udí dáva prednost' rôznym aktivitám a podceňuje učenia, informačno-komunikačné technológie na jednej strane priniesli nebývalé možnosti vzdelávania sa, avšak na druhej strane priniesli aj postoje, resp. prístupy k zl'ahčovaniu významu systematického vzdelávania sa u časti mladých l'udí. Občas sa stretávame s postojmi „všetko je na webe načo sa treba učit"“, „,načo si zat'ažovat' pamät““ a pod. V neposlednom rade aj rôzne sociálne siete „kradnú žiakom čas“. Pre tieto skutočnosti vzrastá význam motivácia v edukácii - žiakov treba viest' $\mathrm{k}$ tomu, aby mali záujem učit' sa, a tak im pomáhat' prekonávat' aj náročnejšie požiadavky a súčasne ich motivačne viest' $\mathrm{k}$ tomu, aby si vedeli organizovat' svoje činnosti.

\section{Vybrané aspekty $z$ teórie motivácie}

Vzhl'adom na tému príspevku nepovažujeme za potrebné podrobne opisovat' podstatu motivácie, avšak na druhej strane nechceme vstúpit' do podstaty príspevky ,in medias res“, preto len pripomenieme základné aspekty motivácie.

Vedome a zámerne ako prvé definovanie uvedieme pohl'ad, ktorý uviedol pred viac ako 80 rokmi Pech, O. (1937: 273) uvádza: „Motivácia učenia je nevyhnutná metóda v škole najmä tam kde žiak nemá prirodzený záujem o učenie. Kedysi bývala motiváciou hlavne autorita učitel'a a rôzne 
disciplinárne motivačné viac-menej tvrdšie prostriedky. Dnes je hlavnou motiváciou záujem... Musí prebúdzat' záujem pre všetky hlavné životné aktivity, musí diagnosticky zistit' skutočné záujmy, ktoré vedú k činnosti, tieto záujmy musia byt' podporované a zachovávané... Škola má tri úlohy: musí vzbudit' záujem o všetky hlavné aktivity v škole, musí diagnosticky zistit' skutočné záujmy, ktoré vedú $\mathrm{k}$ činnosti a v neposlednom rade musí tieto záujmy podporovat' a zachovávat." V uvedenom definovaní je v podstate zdôraznené všetko čo zdôrazňujeme aj dnes.

Definovania motivácie ju prízvukujú ako činnost' zameranú na vzbudenie záujmu, činnost' zameranú na zdržanie pozornosti a aktivity žiaka, ako hybnú silu učenia sa žiaka, ako podnecovanie žiaka do učenia a pod, V tejto súvislosti sa najčastejšie zdôrazňuje úloha učitel'a, napr. využívat' aktivizujúce metódy, správne hodnotit' žiaka, brat' do úvahy jeho predpoklady atd'. To je, samozrejme, správne. V tejto súvislosti však považujeme za podnetný pohl'ad I. Pavelkovej (2002: 23): „Pre školskú motiváciu zohrávajú rozhodujúcu úlohu tri skupiny potrieb. Ide o potreby poznávacie, pretože učebná činnost' predstavuje jednu z významných foriem poznávacej činnosti, potreby sociálne, pretože učebné činnosti sú realizované predovšetkým $\mathrm{v}$ sociálnom kontexte a potreby výkonové, pretože na žiakov sú prostredníctvom úlohových situácií kladené určité požiadavky.“ V uvedenom charakterizovaní je zdôraznený nielen akýsi ,pedagogicko-psychologický tlak“ na žiaka, ale dôraz je položený na komplexnejšie ponímanie motivácie žiaka. To nám pri rôznych úvahách akoby unikalo a dominujú predovšetkým didaktické aspekty motivácie.

V nadväznosti na uvedené pripomenieme ešte pohlad na zásady motivácie podla $\mathrm{K}$. Kruszewského, ktoré opísal v publikácii s priliehavým názvom ,Sztuka nauczania “ (Umenie vyučovat') (2004: 249-258). Sú to tieto: 1. Motivácia do splnenia úlohy je tým silnejšia, čím mocnejšie je žiak presvedčený, že obsah úlohy, podmienky jej splnenia a rozhodnutie o jej význame závisia od neho.

2. Kladný vzt’ah k úlohám zvyšuje motiváciu do činnosti.

3. Úlohy vzbudzujúce zvedavost', záujem žiaka a umožňujúce ich uspokojenie vzbudzujú motiváciu do ich splnenia.

4. Sú žiaci, pre ktorých je hlavným žriedlom motivácie splnenia školských úloh spoločenská akceptácia predovšetkým zo strany učitel’ov, potom rodičov a tiež spolužiakov. Namiesto potreby akceptácie sa môže vyvinút' potreba podriadenia, prispôsobenia sa učitel’om, rodičom alebo spolužiakom, ktorá sa môže stat' dôležitým činitel’om motivujúcim do učenia.

5. Ak žiak považuje vykonanie úlohy za úspech, potom vzrastá aj motivácia do činnosti. Avšak môže platit' aj: Ak žiak vníma nesplnenie úlohy ako neúspech, ,porážku“, vzrastá motivácia do splnenia úlohy.

6. Motivácia do plnenia školských úloh závisí od dížky trvania a sily intenzity akú vyvoláva úloha alebo sprevádzajúce okolnosti.

7. Nielen so zretel'om na úroveň splnenia danej úlohy, ale aj vzhl'adom na širšie ciele učenia je potrebné snažit' sa pretvárat' u žiakov motiváciu vonkajšiu na vnútornú.

Pripomenutím vyššie uvedeného sledujeme akcentovanie, že motivácia neznamená len využivanie akéhosi moderného vyučovania, ale 
dotýka sa mnohých stránok osobnosti žiaka. Realita je však taká, že nie vždy si v edukačnom procese uvedomujeme tieto aspekty.

Pri analýzach edukačného procesu a odporúčaniach pre učitel'ov neraz ostáva pri tom čo sme spomenuli vyššie - využívanie adekvátnych vyučovacích metód, objektívne hodnotenie, povzbudenie žiaka a pod. Len menej sa však zameriavame na zdôrazňovanie aspoň vybraných motivačných teórií. Sú to, napr.:

Teória spravodlivosti (J. S. Adams) - motivácia je individuálnym faktorom individuálneho hodnotenie spravodlivosti. Spravodlivost' možno definovat' ako pomer pracovných vstupov a získaných ocenení. Teória vyjadruje, že motivácia jednotlivca je výsledkom jeho spokojnosti s tým, čo dostáva za svoje úsilie. Správanie osoby do istej miery závisí od typu očakávaných výsledkov. Vo vzt’ahu k edukačnému procesu má značný význam správneho a objektívneho hodnotenia žiakov a citlivý prístup k tejto stránke edukácie.

Maslowova teória hierarchie potrieb (A. H. Maslow) - je vyjadrená tým, že pokial' nie sú uspokojené základné potreby, nemôžu sa sformovat' a prejavit' vyššie potreby človeka. - známa Maslowova pyramídou potrieb. Ak by sme túto „,pyramídu“ dôsledne uplatňovali v každodennej edukačnej realite určite by bolo v školách viacej motivovaných a úspešných žiakov.

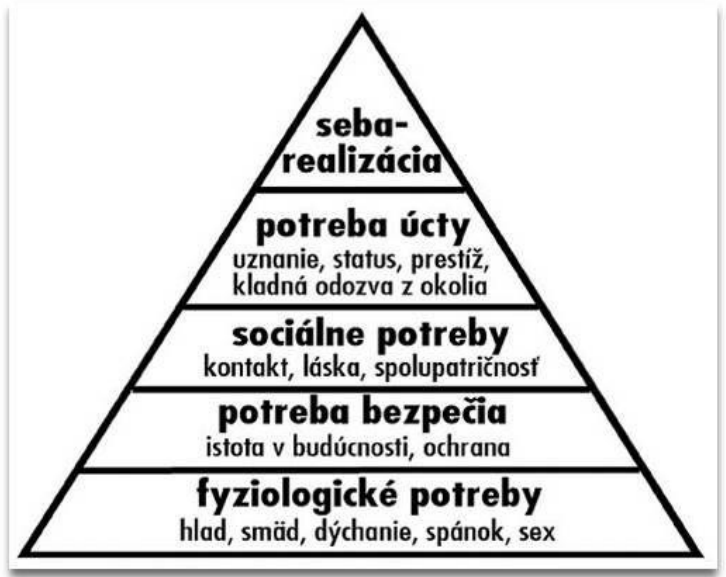

Obr. 1 Maslowova teória hierarchie potrieb (A. H. Maslow)

Teória očakávania (W. Wroom) - jedinca ovplyvňuje jeho vnútorné očakávania. To sa týka:

- ciel'a, ktorý má byt' splnený - očakávanie,

- presvedčenia, že ciel' je splnitel'ný - motivačná sila,

- splnenie ciel'a bude odmenené - úsilie a účinnost' dosiahnutia ciel'a.

Vo vzt'ahu k edukačnému procesu z uvedenej teórie vyplýva potreba, resp. požiadavka stanovovania takých ciel'ov, ktoré vedú žiakov k tomu, aby si verili, že dokážu splnit' požadované úlohy, každé splnenie úlohy by malo byt' ohodnotené.

Teória stanovenia ciel'ov (E. Locke) - stanovovanie si ciel'ov a aj ich dosiahnutie je pre jedinca prirodzené, avšak iba vtedy ak ho chápe a prijíma 
ciel'. Vtedy je jedinec motivovaný a ciel' považuje za splnitel'ný. Vo vzt’ahu $\mathrm{k}$ edukačnému procesu z uvedenej teórie vyplýva potreba, resp. požiadavka, aby žiaci úlohy, ktoré majú plnit' považovali za také, ktoré majú zmysel, ktoré majú ciel', napr. pre d’alšie učenie, pre využitie v ich živote a pod.

Teória posilnenia (B. F. Skinner) - $\mathrm{z}$ tejto teórie vyplýva potreba, resp. požiadavka, aby učitel' posilňoval dobré výsledky a činnosti žiaka.

Teória troch kategórií potrieb (C. Alderfer) - je podobná teórii Maslowa. Potreby sú sústredené, resp. vyjadrené ako:

- existenčné potreby - životné potreby, ale aj ostatné potreby potrebné $\mathrm{k}$ životu,

- potreby spolupatričnosti - vzt’ahy s inými,

- potreby rastu - tvorivé výsledky. Vo vztahu k edukačnému procesu je $\mathrm{z}$ uvedenej teórie podstatný vzt’ah $\mathrm{k}$ iným a potreby rastu. (Armstrong, M., 2007, Belohlavek, F., 2001, Petlak, E., 2019, Zelina, M., 2018)

\section{Motivácia v edukačnom procese}

V texte sme už uviedli, že nebudeme podrobnejšie opisovat' druhy a teórie motivácie a preto pristupujeme $\mathrm{k}$ výsledkom, ktoré sme získali prieskumom názorov a postojov učitel'ov základných škôl v rámci d’alšieho vzdelávania. Ciel’om nášho skúmania bolo vol’nými písomnými vyjadreniami zistit' ako učitelia motivujú žiakov. Pri tomto sme boli inšpirovaný prieskumom, ktorý publikovala B. Dyrda (2006: 127).

Učitelia - zapojených bolo 168 - mali napísat' úplne vol’ne odpoved' na otázku: Akú motiváciu považujú vo svojej práci so žiakmi za najvhodnejšiu. Dôsledne sme žiadali, aby napísali len jednu možnost'. Teda čo sa im v práci osvedčuje, čo využívajú a pod. Pred ich vyjadrením sme uskutočnili krátku prednášku spojenú $\mathrm{s}$ rozhovormi na tému motivácie žiakov. Pre učitel'ov to nebola to l'ahká a jednoduchá odpoved'. Dožadovali, resp. chceli písat' viacej možností. Rozhovorom sme ich však presvedčili, že nám nejde o opis mnohých možností motivácie, ktoré vo svojej pedagogickodidaktickej práci určite využívajú, že máme záujem predovšetkým na tom, aby sme poznali ich názory a čomu v motivácii pripisujú význam. Po vyhodnotení a usporiadaní odpovedí sme zostavili nasledovnú tabul'ku.

Tabul'ka č. 1 - Docenenie motivácie učitel’mi

\begin{tabular}{|l|c|c|}
\hline \multicolumn{1}{|c|}{ Motivácia } & Počet & $\mathbf{\%}$ \\
\hline Rôzne motivačné metódy & 38 & 22,62 \\
\hline Motivácia prostredníctvom inovácií & 32 & 19,05 \\
\hline Hodnotenie žiakov & 31 & 18,45 \\
\hline Kontrola žiakov & 29 & 17,26 \\
\hline Rôzne sút’aže vo vyučovaní & 19 & 11,31 \\
\hline Prísnost' učitela & 10 & 5,95 \\
\hline Rôzne - iné možnosti & 9 & 5,36 \\
\hline Spolu & $\mathbf{1 6 8}$ & $\mathbf{1 0 0 , 0 0}$ \\
\hline
\end{tabular}


Zo získaných výsledkov je zrejmé, že v edukačnom procese učitelia najčastejšie využívajú klasické prístupy k motivovaniu.

V skupine - rôzne motivačné metódy - to boli vyjadrenia: motivovanie cielom hodiny, motivovanie rozhovorom, problémovými situáciami, aktualizáciou učiva a pod. V uvedených odpovediach učitelia prejavili didaktické a psychologické vedomosti, avšak väčšina ostala len pri klasickom ponímaní motivácie. To sa v podstate vzt’ahujeme na všetky získané vyjadrenia učitel'ov. S istým uspokojením konštatujeme, že 19,05 \% učitel'ov sa vyjadrilo, že motivujú žiakov prostredníctvom využívania inovatívnych prístupov k vyučovaniu. Aj ked' percento týchto učitel'ov nie je vysoké predsa naznačuje, že v edukácii je venovaná pozornost' tvorivejším prístupom k motivácii. Do motivovania „prostredníctvom inovácii““ sme zaradili odpovede, napr.: motivovanie využivaním tvorivého vyučovania, motivovanie využívaním skupinovej práce žiakov, motivovanie konštruktivistickým vyučovaním, motivovanie preferovaním vlastnej tvorivosti žiakov a pod. Z uvedeného je zrejmé, že čast' učitel'ov doceňuje a využíva inovácie v edukácii nielen ako istú požiadavku súčasnej edukácie, ale spolu s tým aj ako možnost' tvorivejšieho zapojenia žiakov do edukácie.

Zmienime sa ešte o položke rôzne - iné možnosti 5,36 \%. Samozrejme, nezastierame, že uvedený počet vyjadrení považujeme za nízky. Vnímame ho však ako realitu, resp. ako reflexiu edukačnej praxe v školách. V uvedenej oblasti sme zaznamenali vyjadrenia: motivujem žiaka podla jeho povahy, pri motivácii uplatňujem nie to čo chcem ja, ale vychádzam zo žiakov, najprv zistím čo žiaci vedia o učive a potom s nimi hovorím ako to môžeme zdokonalit' a obohatit', základom motivácie je poznanie žiakov, bez toho sa nedá motivovat' a pod. Uvedené odpovede svedčia o tom, že v školách máme učitel’ov, ktorí „prekračujú hranice“ tzv. klasických prístupov motivácie a vo svojej praxi využívajú aj novšie prístupy. Doceňujú a uvedomujú si, že žiakov motivujú nielen rokmi printované a zdôrazňované vstupné a priebežné motivačné metódy, ale celý systém práce učitel'a so žiakmi. To je podrobne opísané v publikácii E. Petlak (2019).

Uvedené výsledky nášho zist'ovania potvrdili, že učitelia ešte stále zotrvávajú na tradičných prístupoch motivácie. Ak však zdôrazňuje Brophy (2002: 76) uvedené prístupy nie sú celkom vyhovujúce, pretože viaceré $\mathrm{z}$ nich, napr. motivovanie hodnotením, rôznymi sút’ažami v triede a pod., majú negatívny vplyv na vnútornú motiváciu žiaka. Viaceré klasické a aj zaužívané motivačné metódy sú v podstate istým tlakom na žiaka. Namiesto nich sa musia v edukácii uplatňovat' a využívat' metódy vnútornej motivácie.

\section{Vzt'ah medzi motiváciou žiakov a prácou učitel’a}

O motivácii žiakov v edukačnom procese je napísaných priam nespočetné množstvo článkov, ale aj kníh. Ak vychádzame z počtu štúdií a uskutočnených výskumov využívania motivácie v reálnom edukačnom procese by nemali byt' problémy - teória poskytuje naozaj vel'a overených postupov. Ako sme však naznačili vyššie realita edukácie nie je celkom uspokojivá. Príčin je určite viacej, napr. obsah učiva, postoje žiakov ku vzdelávaniu, využívanie novších metód a foriem edukácie, ktoré by, povedané v dobrom zmysle slova eliminovali záujem žiakov s IKT, ktoré sú 
nie vždy využívané na vzdelávanie (napr. kritika na viaceré aspekty plynúce zo sociálnych sietí a pod.).

$\mathrm{V}$ ostatných rokoch sa $\mathrm{z}$ hladiska motivácie prikladá význam nielen tomu ako učitel' pracuje vo vyučovaní, ale aj tomu ako je spokojný so svojou prácou, pretože spokojnost' alebo nespokojnost' učitel'a ovplyvňuje edukáciu. Pravdou je, že v tejto oblasti nemáme u nás relevantné výsledky a štúdie, ktoré by komplexne posudzovali a vyhodnocovali spokojnost' alebo nespokojnost' učitel'ov so svojou prácou. Pritom vieme, že spokojnost', a to nielen v edukácii, o. i. podnecuje $\mathrm{k}$ tvorivej práci.

Je vel'a oblastí, ktoré by sme si mali pozornejšie všímat', zistovat' a vyhodnocovat' ich a na zistenom základe pristupovat' aj k požiadavkám kladeným na edukačné činnosti učitel'a. V literature, napr. Müller, F. H., Hanfstingl, B., 2010: 6) sa najčastejšie uvádzajú nasledovné:

- osobné predpoklady učitel’a (záujem o prácu, resp. "povinnost' pracovat")

- podmienky prostredia, napr. pracovné podmienky,

- postoje žiakov alebo aj študentov k edukácii a vôbec k učitel'om a školským požiadavkám,

- symbióza motivácie učitel’a s motiváciou žiakov - uvedená oblast' je jednou z tých, ktorá si zasluhuje systematickejšie a dlhodobejšie skúmanie, pretože tendencia je posudzovanie priebehu a výsledkov učenia sa žiakov len podla činností učitel'a, avšak menej podla vzájomného vzt’ahu motivácie učitel'a a žiakov; ide tu o podobný stav ako zosúladenie štýlu práce učitel’a s učebnými štýlmi žiakov,

- pozornost' si zasluhuje aj skúmanie veku žiakov na motivačné prístupy učitel’ov, neraz si neuvedomujeme zásadné rozdiely v motivácii, napr. pri skupinovej, tímovej spolupráci atd'.,

- ak vychádzame $\mathrm{z}$ výsledkov edukácie $\mathrm{v}$ našich školách, potom treba uviest', že motivácia je oblast'ou, ktorá by mala byt' ovel'a viac docenená aj v d'alšom vzdelávaní učitel'ov ( $\mathrm{k}$ takémuto konštatovaniu nás vedú, napr. výsledky PISA).

V spomínanom prieskume zistovaní názorov učitel'ov sme ich požiadali, aby napísali ako sú spokojní a motivovaní do svojej edukačnej činnosti. Zámerne sme sa nepýtali a ani sme nežiadali, aby písali s čím sú nespokojní, pretože by písali, okrem platových aspektov, o náročnosti obsahu vzdelávania, o nezáujme detí o vzdelávaní, o nie dobrých učebniciach a pod. Tomu sme sa chceli vyhnút', a teda naša požiadavka bola, aby uviedli: ako vnímajú, resp. ako prežívajú spokojnost' so svojou prácou, čo ich motivuje do práce. Výsledky sme vyhodnotili a uvádzame ich v tabul'ke č. 2.

Tabul'ka č. 2 - Spokojnost' učitel'ov s prácou, motivácia do práce.

\begin{tabular}{|c|c|c|}
\hline Činitel' spokojnosti & Počet & \% \\
\hline Práca ma baví a som spokojný & 34 & 20,24 \\
\hline $\begin{array}{c}\text { Som spokojný s mojim odborným } \\
\text { rastom }\end{array}$ & 33 & 19,64 \\
\hline $\begin{array}{c}\text { Motivujú ma výsledky práce } \\
\text { žiakov }\end{array}$ & 27 & 16,07 \\
\hline
\end{tabular}




\begin{tabular}{|c|c|c|}
\hline $\begin{array}{c}\text { Vedenie školy má záujem o moju } \\
\text { prácu }\end{array}$ & 22 & 13,10 \\
\hline Môžem využivat' vlastnú tvorivost' & 20 & 11,90 \\
\hline Práca je náročná, ale motivujúca & 18 & 10,72 \\
\hline $\begin{array}{c}\text { Kratší pracovný čas - využívam na } \\
\text { štúdium }\end{array}$ & 10 & 5,95 \\
\hline Pracovné zat’aženie - primerané & 4 & 2,38 \\
\hline Spolu & $\mathbf{1 6 8}$ & $\mathbf{1 0 0 , 0 0}$ \\
\hline
\end{tabular}

Zo získaných odpovedí je zrejmé, že učitelia si uvedomujú pozitíva svojej práce, a to $\mathrm{z}$ viacerých aspektov. Ich odpovede do istej miery narúšajú zauživané a vostatných rokoch azda aj zveličované konštatovania o zlej situácii učitel'ov o ich nespokojnosti s prácou a pod. Isteže, je vel'a oblastí, ktoré sú predmetom kritiky zo strany učitel'ov a zaznamenali sme ich aj počas spomenutého d'alšieho vzdelávania učitel'ov. V zásade sú to však pripomienky, ktoré sú celkom bežné v každej profesii, napr. lepšia spätná väzba na prácu, promptnejšie informovanie o zámeroch školstva, časové možnosti na zoznamovanie sa s novými požiadavkami zo strany riadiacich orgánov atd'. Tieto požiadavky a námety nie sú však antagonistického rázu, sú to, takpovediac všeobecné a v istom zmysle aj „trvalé požiadavky“ ktoré súvisia so zvyšujúcimi sa nárokmi na edukačnú prácu. $\mathrm{V}$ istom zmysle ich môžeme vnímat' aj ako spätnú väzbu na dianie v školstve zo strany učitel'ov. Pravdaže, zastávame názor, že ani tieto námety a pripomienky učitel’ov nemožno podceňovat, ale naopak, pretože sú zdrojom námetov vedúcich $\mathrm{k}$ lepšej edukácii. $\mathrm{V}$ myslení učitel'ov majú značný motivačný význam reagovanie a akceptovanie ich názorov. $V$ tomto zmysle využijeme paralelu: ak doceníme postoje a názory žiaka bude viac motivovaný do učebnej činnosti. Teda, ak budem načúvat' námetom a hlasom učitel'ov, budú viacej motivovaní do edukačnej činnosti.

\section{Záver}

Ciel'om uvedeného príspevku je predovšetkým upriamenie pozornosti na motiváciu ako základný predpoklad úspešnosti a efektívnosti edukačného procesu. Vnímame ho ako úvodnú štúdiu k článkom, ktoré budú nasledovat' a sú výsledkom skúmaní dotazníkovou metódou, fokusovými skupinami a rozhovormi s učitel'mi. Pri téme a jej spracovaní vychádzame z toho, že „motivácia je to čo každý vie a nikto nevie“. Týmto vyjadrením chceme povedat', že každý si uvedomuje jej význam a dôležitost', ba aj rôzne možnosti realizácie a pod. Realita je však ovel’a zložitejšia ako si uvedomujeme pri bežnom uvažovaní o motivácii. Motivácia nie je len pôsobenie učitela na žiaka takými alebo onakými metódami. Motiváciou zasahujeme pôsobíme na celú osobnost' žiaka a naša motivácia sa u žiaka „láme“ na jeho osobnosti, na jeho záujmoch, na jeho zážitkoch, na jeho skúsenostiach, na jeho postojoch, na jeho..... Ako ukazujú skúsenosti motivácia musí byt' neustále $\mathrm{v}$ centre pozornosti učitel'ov, pedagógov a psychológov. Dnešok, na jednej strane ponúka mnoho motivačných možností pre vzdelávanie sa, na druhej strane však nie sú neznáme ani demotivujúce vplyvy. 


\section{Bibliographic references}

ARMSTRONG, M. 2007. Řízení lidských zdrojů. Praha, Grada, ISBN 97880-247-1407-3.

BELOHLAVEK, F. 2001. Management. Olomouc, Rubico, 642 p. ISBN 80858-3945-8.

BROPHY, J. 2002. Motywowanie uczniów do nauki. Warszawa, WN PWN, ISBN 83-01-13655-3.

DYRDA, B. 2006. Motywowanie ucznillw do nauki - zadanie wspolzesnego nauczyciela. In Chowanna č.1, pp. 121 -131, ISSN 0137-706X.

MULLER, F. H., HANFSTINGL, B. 2010. Teacher motivation. [cit. 9. 8. 2020] Avauilable online: htttps://www.questia.com/library/p439513/journalfor-educational-research-online

KRUSZEWSKI, K. 2004. Sztuka nauczania. Czynności nauczyciela. Warszawa, WN PWN, ISBN 83-01-14239-1.

PAVELKOVA, I. 2002. Motivace žaků k učení: Perspektivní orientace žáků a časový faktor v žákovské motivaci. Praha, PF KU, ISBN 80-7290-092-7.

PETLÁK, E. 2019. Motivácia v edukačnom procese. Bratislava, Wolters Kluwer, ISBN 978-80-571-0150-5.

ZELINA, M. 2018. Kompetencie osobnosti pre buducnost. In Studia Scientifica Facultatis Paedagogicae, Ružomberok, Verbum, ISSN 1336-2232.

114 prof. PhDr. Erich Petlák, CSc.

Faculty of education

Catholic University in Ruzomberok

Hrabovská cesta 1

03401 Ružomberok

Slovakia

erich.petlak@ku.sk 